\title{
Present Status of Khasi Mandarin in Manipur State of North East India
}

\author{
R.K. Kakoti*, Jamini Saikia, Sikha Deka, Arunima Gogoi and A.C. Barbora \\ Citrus Research Station, Assam Agricultural University, Tinsukia - 786125, India \\ *Corresponding author
}

\begin{abstract}
A B S T R A C T
Keywords

Growth, Khasi

Mandarin, Quality,

Status, Yield

Article Info

Accepted:

17 May 2019

Available Online:

10 June 2019

Khasi Mandarin (Citrus reticulata Blanco.) is one of the most widely cultivated and important commercial fruit crop of North East India. A survey was conducted in Mandarin orchards from three district of Manipur viz., Tamenglong, Bishnupur and Noney during 2018 to study the present status of Khasi Mandarin in Manipur with growth, yield and quality parameters. The Mandarin fruits were evaluated morphologically and biochemically for different parameters. It was observed that all the three district of Manipur was found to have Khasi Mandarin in the orchards but it was gradually declined. Incidence of various diseases, lower nutrient concentration and lack of disease free quality planting materials are the bottlenecks accounting for overall low average productivity of 8.83 t/ha. Though at present Manipur have limited area under Khasi mandarin, but their quality was found superior. All the three districts recorded superior quality fruits in respect of juice content (\%), acidity (\%), TSS ( ${ }^{\circ}$ Brix), TSS: Acidity and Ascorbic acid (mg/100 $\mathrm{ml}$ ) content. Among the growth, yield and yield attributing parameters, the three districts showed significant difference for all the characters studied.
\end{abstract}

\section{Introduction}

North eastern region of India is known for commercial production of Khasi Mandarin (Citrus reticulata Blanco.) and considered as one of the most important centers of origin of Citrus species. It is the most popular and a commercially widely cultivated variety of North Eastern States. Due to the global problem of citrus decline, production of Khasi Mandarin in North East India is gradually going to be low. Mandarin orchards start to decline in production after satisfactory performance for few years. The decline of productivity has been attributed to various factors like plantation on unsuitable land, lack of quality planting materials, inadequate nutrition and incidence of insect-pest and diseases. Citrus decline involves the defoliation of young shoots and dying back of twigs from the tip downwards, resulting in loss of vigour, general health and decreased fruit production. This ultimately leads to decline of productivity to a greater extent (Yadav et al., 2003). In India, citrus is cultivated over an area of about 1,055 thousand hectares with a production of 12,746 thousand metric tons and the productivity of 12.08 MT/ha. Out of this, Khasi Mandarin alone occupies an area of 429 thousand 
hectares with a production of 4754 thousand metric tons and the productivity of 11.08 MT/ha. However, the farmers of Manipur cultivate Khasi Mandarin in an area of about 4.89 thousand hectares with production of 43.18 thousand metric tons and the productivity is $8.83 \mathrm{MT} / \mathrm{ha}$ (Horticultural Statistics at a Glance, 2016-17). If we compare this data with five years back, i.e. in 2012-13, the area under Khasi Mandarin crop is relatively going to be low which was 5.02 thousand hectares and production was 32.64 thousand metric tons (National Horticulture Board, 2009). Therefore, a survey was done in Manipur state to study the present status of Khasi Mandarin.

\section{Materials and Methods}

The study was conducted in the district of Manipur viz., Tamenglong, Bishnupur and Noney during 2017. The geographical coordinates of three districts are: Tamenglong (latitude $24^{\circ} 58^{\prime} 35^{\prime \prime} \mathrm{N}$ and longitude $93^{\circ} 29^{\prime}$ $58^{\prime \prime} \mathrm{E}$ ), Bishnupur (latitude $24^{\circ} 37^{\prime} 52^{\prime \prime} \mathrm{N}$ and longitude $93^{\circ} 45^{\prime} 46^{\prime \prime} \mathrm{E}$ ) and Noney (latitude $24^{\circ} 54^{\prime} 51^{\prime \prime} \mathrm{N}$ and longitude $93^{\circ} 29^{\prime} 24^{\prime \prime} \mathrm{E}$ ). For the study, five mandarin grower's orchards from each of the three districts were selected randomly. Twenty plants from each of the five orchards from each district were selected to study the tree characters, yield and yield attributing characters and quality characters of the fruits. The morphological parameters were recorded in the orchards itself. The biochemical and soil parameters were carried out at Citrus Research Station, Assam Agricultural University, Tinsukia. Soil samples were collected according to the procedures of soil sample collection from different orchards. Symptomatic leaves with twigs using standard sampling technique were collected from 15 orchards for detection of Citrus greening disease. Data on growth and yield parameters viz., plant height (m), stem girth $(\mathrm{cm}), \mathrm{N}-\mathrm{S}$ plant spread $(\mathrm{m}), \mathrm{E}-\mathrm{W}$ plant spread $(\mathrm{m})$, fruit length $(\mathrm{cm})$, fruit diameter $(\mathrm{cm})$, number of fruits per plant, fruit yield per plant $(\mathrm{kg})$, fruit yield $(\mathrm{t} / \mathrm{ha})$ and fruit weight $(\mathrm{g})$; quality parameters of the fruits viz., juice content (\%), acidity (\%), TSS ( ${ }^{\circ}$ Brix), TSS: Acidity and ascorbic acid (mg/100 ml) and soil parameters viz., Fe, Mn, $\mathrm{Cu}$ and $\mathrm{Zn}$ content were recorded. The data was statistically analyzed by applying Fisher's analysis of variance (Panse and Sukhatme, 1989).

\section{Results and Discussion}

\section{Growth and yield parameters}

The data presented in Table 1 reveals that the growth and yield parameters of Khasi Mandarin showed significant difference among different districts of different orchards. The highest plant height was recorded for the Tamenglong $(8.20 \mathrm{~m})$ in orchard $1 \mathrm{~b}$ which was at par with Tamenglong in orchard no. 1d $(8.13 \mathrm{~m})$ and Noney in orchard $3 \mathrm{e}$ and $3 \mathrm{~d}$ $(8.07 \mathrm{~m}$ and $8.03 \mathrm{~m})$. Bishnupur recorded the lowest plant height $7.03 \mathrm{~m}$ in orchard $2 \mathrm{c}$. Hangsing et al., (2016) reported plant height of $6.48 \mathrm{~m}$ to $4.60 \mathrm{~m}$ in Garo Hills of Meghalaya. In case of stem girth, the highest stem girth $15.50 \mathrm{~cm}$ was recorded for the district Temenglong in orchard $1 \mathrm{~b}$ which was at par with all other orchards of Tamenglong and Noney district. The lowest stem girth of $14.00 \mathrm{~cm}$ was recorded for Bishnupur district in orchard 2c. From this result, we can say that growth parameters were recorded highest for Tamenglong district which was more or less similar with Noney district. This highest result was might be due to application of adequate nutrients to the plants. In case of fruit length $(7.33 \mathrm{~cm})$ and fruit breadth $(8.43 \mathrm{~cm})$, Tamenglong again recorded the highest in orchard 1c. The lowest fruit length and fruit breadth $(5.23 \mathrm{~cm}$ and $6.67 \mathrm{~cm})$ was recorded for Bishnupur in orchard $2 \mathrm{a}$. Maximum number of fruits per plant 126.00 
was recorded for the district Tamenglong in orchard 1a which was at par with all other orchards of Tamenglong, Noney and Bishnupur except for the orchard $2 b$ of Bishnupur district. Fruit weight was recorded highest (243.55g) for Tamenglong district in orchard $1 \mathrm{~b}$ which was at par with same district of orchard 1c (239.02g), 1a (236.62g) and $1 \mathrm{~d}(228.39 \mathrm{~g})$, respectively. The lowest fruit weight (133.31g) was recorded for Bishnupur district in orchard $2 \mathrm{~b}$. Hangsing et al., (2016) recorded highest fruit weight of $130.69 \mathrm{~g}$ for the Garo Hills of Meghalaya. Further, Tamenglong district again recorded highest fruit yield/plant $(28.33 \mathrm{~kg})$ in orchard $1 \mathrm{~b}$ which was at par with all other orchards of Tamenglong and Noney district. The lowest fruit yield/plant $(11.08 \mathrm{~kg})$ was recorded for Bishnupur district in orchard 2b. Again, fruit yield was observed to be highest in the district Tamenglong (11.32t/ha) in orchard $1 \mathrm{~b}$ which was at par with all other orchards of Tamenglong and Noney district. The lowest fruit yield (4.54t/ha) was recorded for Bishnupur district in orchard 2b. Sarangthem and Sharma (2017) found fruit number ranged from 310 to 80 and fruit yield per plant ranged from 46.8 to $11.6 \mathrm{~kg} /$ plant in case of Khasi Mandarin in Tamenglong district of Manipur. From the present investigation, it was observed that the yield of Khasi Mandarin is gradually going to be decline due to heavy infestation of insect pest and diseases with inadequate application of nutrients. Das et al., (2004) reported fruit length of $5.28 \mathrm{~cm}$ and fruit diameter of 5.22 $\mathrm{cm}$ on Khasi Mandarin in Meghalaya, which was also corroborate with the present finding. Medhi et al., (2007) reported fruit weight $113.3 \mathrm{~g}$ to $159.6 \mathrm{~g}$ of Khasi Mandarin in Assam.

\section{Quality parameters}

The quality parameters of Khasi Mandarin fruits from each orchard of three districts were analyzed, recorded and presented in
Table 2. It was observed that there was significant difference among the three districts for biochemical traits. The highest juice content of $46.53 \%$ was recorded for Tamenglong district with orchard 1e which was at par with all other orchard of Tamenglong and Noney district. The lowest juice content of $41.40 \%$ was recorded for Bishnupur district with orchard 2d. Regarding acidity content, minimum acidity content of $0.62 \%$ was recorded for the district Tamenglong with orchard $1 \mathrm{~b}$ and $1 \mathrm{~d}$; Whereas, Bishnupur district recorded highest $0.69 \%$ acidity content in orchard $2 \mathrm{~d}$. Further, Tamenglong district again recorded highest TSS content $\left(12.33{ }^{0}\right.$ Brix $)$ in orchard 1a. Similar TSS content of $12.33{ }^{0}$ Brix was also recorded for Noney district in orchard 3a. The lowest TSS content of $10.00{ }^{0}$ Brix was recorded for Bishnupur district in orchard $2 b$ which was statistically at par with all other orchards of Bishnupur. In respect of TSS: acidity ratio, Tamenglong recorded highest 18.80 which were at par with all other orchards of Tamenglong and Noney district. Bishnupur district recorded lowest (14.24) TSS: Acidity ratio in orchard $2 \mathrm{c}$ which was at par with all other orchards of Bishnupur. Medhi et al., (2007) reported fruit acidity ranging from 0.42 to $0.48 \%$ and TSS ranged from 9.28 to $10.80{ }^{0}$ Brix of Khasi Mandarin in Assam. Again, the highest ascorbic acid content $50.49 \mathrm{mg} / 100 \mathrm{ml}$ was recorded for the district Tamenglong in orchard $1 \mathrm{~b}$ which was statistically at par with all other orchard of Tamenglong and Noney district. The lowest ascorbic acid content of $38.34 \mathrm{mg} / 100 \mathrm{ml}$ was recorded for Bishnupur district in orchard $2 \mathrm{a}$. Das et al., (2004) reported ascorbic acid content of $21 \mathrm{mg} / 100 \mathrm{ml}$ in Khasi mandarin. Yadav et al., (2003) reported 28.40 to 35.50 $\mathrm{mg} / 100 \mathrm{ml}$ of ascorbic acid content in Khasi mandarin. Medhi et al., (2007) reported ascorbic acid of 43.82 to $50.44 \mathrm{mg} / 100 \mathrm{ml}$ in Khasi Mandarin fruits in Assam (Fig. 1 and 2). 
Fig.1 Khasi Mandarin orchards of Tamenglong, Noney and Bishnupur district

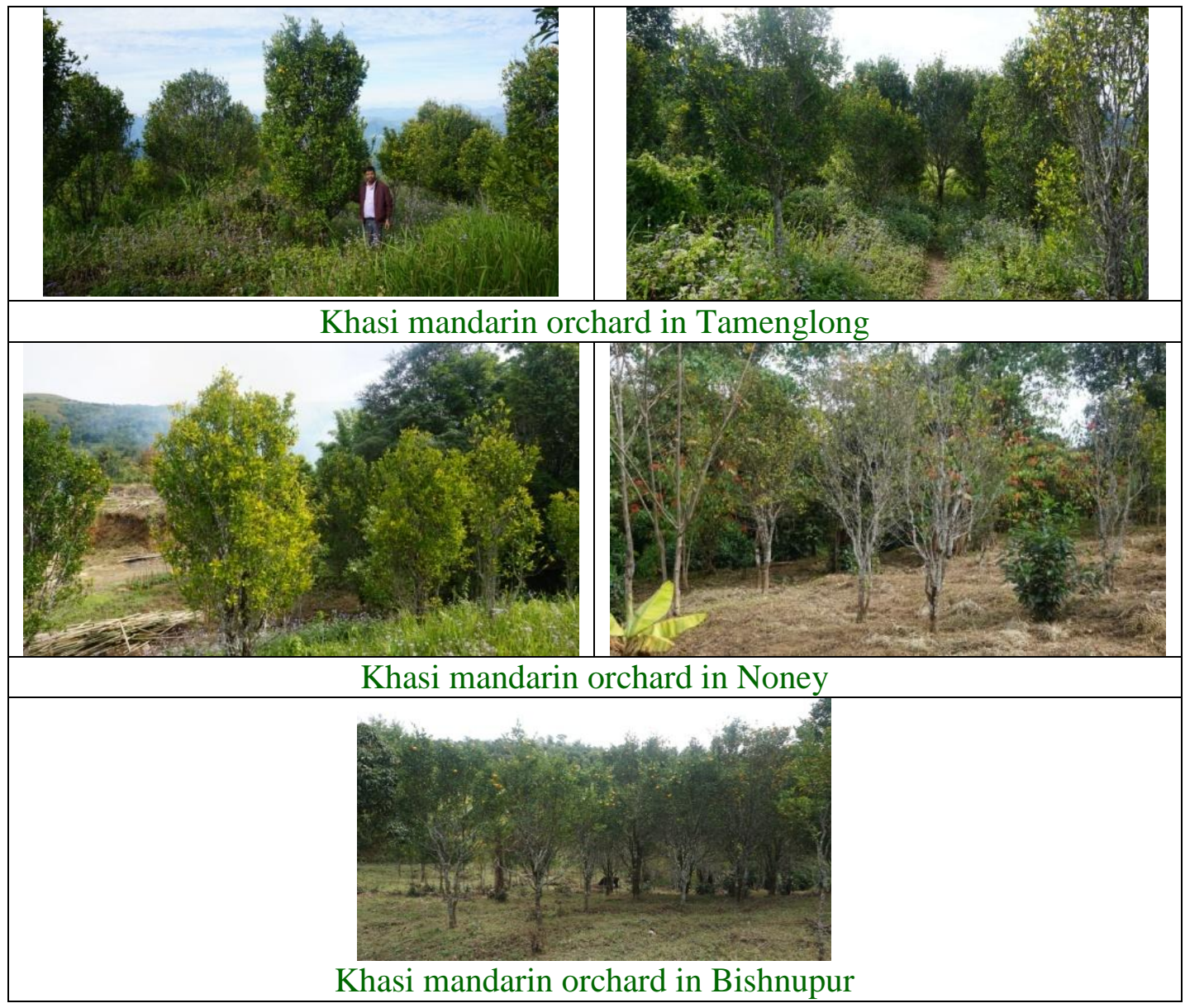

Fig.2 Khasi Mandarin fruits from different districts
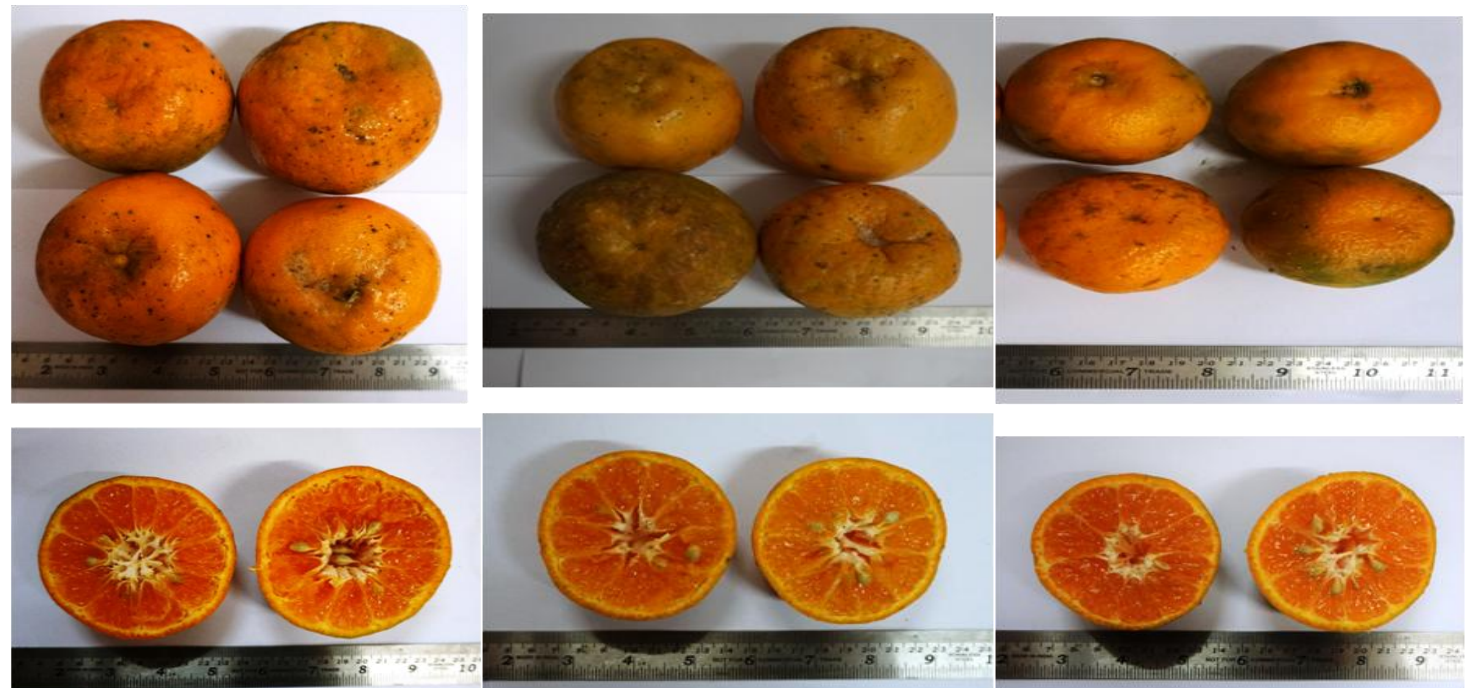

Tamenglong

Bishnupur

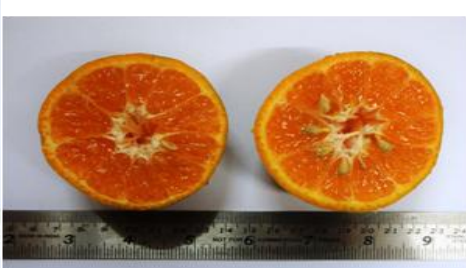

Noney 
Table.1 Growth and yield parameters of Khasi Mandarin in three districts of Manipur

\begin{tabular}{|c|c|c|c|c|c|c|c|c|}
\hline $\begin{array}{l}\text { Districts with } \\
\text { orchards }\end{array}$ & $\begin{array}{l}\text { Plant } \\
\text { height } \\
\text { (m) }\end{array}$ & $\begin{array}{l}\text { Stem } \\
\text { girth } \\
(\mathrm{cm}) \\
\end{array}$ & $\begin{array}{l}\text { Fruit } \\
\text { length } \\
\text { (cm) }\end{array}$ & $\begin{array}{c}\text { Fruit } \\
\text { breadth } \\
(\mathbf{c m})\end{array}$ & $\begin{array}{l}\text { Fruits } \\
\text { /plant }\end{array}$ & $\begin{array}{c}\text { Fruit } \\
\text { weight } \\
\text { (g) }\end{array}$ & $\begin{array}{l}\text { Fruit yield } \\
\text { /plant } \\
\text { (kg) }\end{array}$ & $\begin{array}{c}\text { Fruit yield } \\
\text { (t/ha) }\end{array}$ \\
\hline Tamenglong & & & & & & & & \\
\hline 1a & 7.73 & 14.93 & 6.53 & 7.63 & 126.00 & 236.62 & 25.87 & 10.35 \\
\hline 1b & 8.20 & 15.50 & 7.23 & 8.03 & 119.33 & 243.55 & 28.33 & 11.32 \\
\hline 1c & 7.57 & 15.23 & 7.33 & 8.43 & 112.00 & 239.02 & 22.67 & 9.27 \\
\hline 1d & 8.13 & 15.30 & 7.17 & 8.27 & 122.00 & 228.39 & 25.36 & 10.14 \\
\hline $1 e$ & 7.87 & 15.00 & 6.67 & 8.03 & 123.00 & 216.30 & 26.93 & 10.77 \\
\hline Bishnupur & & & & & & & & \\
\hline $\mathbf{2 a}$ & 7.27 & 14.40 & 5.23 & 6.67 & 95.67 & 152.68 & 15.13 & 6.07 \\
\hline $2 b$ & 7.67 & 14.33 & 5.60 & 7.17 & 82.33 & 133.31 & 11.08 & 4.54 \\
\hline $2 c$ & 7.03 & 14.00 & 6.00 & 6.80 & 87.33 & 150.69 & 13.16 & 5.27 \\
\hline 2d & 7.07 & 14.63 & 5.63 & 6.80 & 92.67 & 181.06 & 21.40 & 8.56 \\
\hline $2 e$ & 7.63 & 14.56 & 6.20 & 7.00 & 96.67 & 145.10 & 14.02 & 5.70 \\
\hline Noney & & & & & & & & \\
\hline $3 \mathbf{a}$ & 7.40 & 14.73 & 7.00 & 8.37 & 109.67 & 208.07 & 25.30 & 10.14 \\
\hline $3 b$ & 7.93 & 15.17 & 6.77 & 7.30 & 116.67 & 209.00 & 24.85 & 9.96 \\
\hline $3 c$ & 7.70 & 15.23 & 6.93 & 8.10 & 99.33 & 189.43 & 21.13 & 8.46 \\
\hline $3 d$ & 8.03 & 15.20 & 6.57 & 7.67 & 99.00 & 208.40 & 22.51 & 9.00 \\
\hline $3 e$ & 8.07 & 15.43 & 6.80 & 7.63 & 101.00 & 216.81 & 24.90 & 10.05 \\
\hline $\begin{array}{c}\text { SEd }(\stackrel{ \pm}{\overline{ \pm}}) \\
\text { CD at } 5 \%\end{array}$ & $\begin{array}{l}0.38 \\
0.77\end{array}$ & $\begin{array}{l}0.41 \\
0.83\end{array}$ & $\begin{array}{l}0.31 \\
0.63\end{array}$ & $\begin{array}{l}0.32 \\
0.66\end{array}$ & $\begin{array}{l}16.01 \\
32.82\end{array}$ & $\begin{array}{c}9.42 \\
19.30\end{array}$ & $\begin{array}{l}3.55 \\
7.28\end{array}$ & $\begin{array}{l}1.40 \\
2.87\end{array}$ \\
\hline
\end{tabular}


Table.2 Quality parameters of Khasi Mandarin in three districts of Manipur

\begin{tabular}{|c|c|c|c|c|c|}
\hline Orchard No. & Juice content (\%) & Acidity (\%) & $\begin{array}{c}\text { TSS } \\
\left({ }^{0} \text { Brix }\right)\end{array}$ & TSS: Acidity & $\begin{array}{c}\text { Ascorbic acid } \\
(\mathrm{mg} / 100 \mathrm{ml})\end{array}$ \\
\hline 1. Tamenglong & & & & & \\
\hline $\mathbf{1 a}$ & 45.64 & 0.64 & 12.33 & 18.05 & 47.76 \\
\hline $1 b$ & 44.67 & 0.62 & 12.00 & 18.67 & 50.49 \\
\hline $1 c$ & 45.69 & 0.64 & 11.67 & 18.80 & 47.96 \\
\hline 1d & 46.21 & 0.62 & 11.67 & 17.82 & 44.08 \\
\hline $1 e$ & 46.53 & 0.65 & 12.00 & 18.05 & 50.31 \\
\hline 2. Bishnupur & & & & & \\
\hline $\mathbf{2 a}$ & 41.58 & 0.68 & 10.33 & 14.59 & 38.34 \\
\hline $\mathbf{2 b}$ & 43.44 & 0.67 & 10.00 & 14.67 & 42.02 \\
\hline $2 \mathrm{c}$ & 42.49 & 0.66 & 10.33 & 14.24 & 42.96 \\
\hline $2 d$ & 41.40 & 0.69 & 11.00 & 15.55 & 39.56 \\
\hline $2 \mathrm{e}$ & 42.50 & 0.66 & 10.67 & 15.61 & 41.50 \\
\hline 3. Noney & & & & & \\
\hline $3 \mathbf{a}$ & 44.49 & 0.65 & 12.33 & 18.33 & 45.87 \\
\hline $3 \mathbf{b}$ & 45.30 & 0.64 & 11.33 & 17.33 & 44.34 \\
\hline $3 c$ & 43.13 & 0.65 & 12.67 & 17.89 & 44.21 \\
\hline $3 d$ & 44.21 & 0.65 & 11.67 & 18.11 & 49.74 \\
\hline $3 e$ & 44.69 & 0.64 & 12.00 & 17.95 & 48.31 \\
\hline $\begin{array}{c}\text { SEd }(\stackrel{ \pm}{ \pm}) \\
\text { CD at } 5 \%\end{array}$ & $\begin{array}{l}1.61 \\
3.30\end{array}$ & $\begin{array}{l}0.02 \\
0.05\end{array}$ & $\begin{array}{l}0.85 \\
1.74\end{array}$ & $\begin{array}{l}1.46 \\
2.99\end{array}$ & $\begin{array}{l}3.59 \\
7.36\end{array}$ \\
\hline
\end{tabular}


Table.3 Micronutrient status of Khasi Mandarin in three districts of Manipur

\begin{tabular}{|c|c|c|c|c|}
\hline Orchard No. & $\mathrm{Fe}(\mathrm{mg} / \mathrm{kg})$ & Mn (mg/kg) & $\mathrm{Cu}(\mathrm{mg} / \mathrm{kg})$ & Zn (mg/kg) \\
\hline Tamenglong & & & & \\
\hline $\mathbf{1 a}$ & 84.88 & 22.09 & 0.87 & 0.75 \\
\hline $1 b$ & 81.75 & 21.02 & 0.85 & 0.67 \\
\hline 1c & 81.23 & 19.03 & 0.83 & 0.70 \\
\hline 1d & 79.48 & 21.36 & 0.76 & 0.59 \\
\hline 1e & 77.60 & 21.04 & 0.74 & 0.68 \\
\hline 2. Bishnupur & & & & \\
\hline $2 \mathbf{a}$ & 71.41 & 19.66 & 0.65 & 0.47 \\
\hline $2 b$ & 69.09 & 20.09 & 0.63 & 0.49 \\
\hline $2 c$ & 75.82 & 19.20 & 0.61 & 0.55 \\
\hline 2d & 75.25 & 18.92 & 0.59 & 0.59 \\
\hline $2 e$ & 66.20 & 18.28 & 0.57 & 0.61 \\
\hline 3. Noney & & & & \\
\hline $\mathbf{3 a}$ & 79.79 & 21.30 & 0.78 & 0.66 \\
\hline $3 \mathbf{b}$ & 81.61 & 20.31 & 0.72 & 0.58 \\
\hline $3 c$ & 82.72 & 20.71 & 0.69 & 0.57 \\
\hline 3d & 76.52 & 19.64 & 0.80 & 0.69 \\
\hline $3 \mathbf{e}$ & 75.99 & 19.88 & 0.70 & 0.69 \\
\hline $\begin{array}{c}\text { SEd }(\stackrel{ \pm}{)}) \\
\text { CD at } \stackrel{5 \%}{0}\end{array}$ & $\begin{array}{l}1.98 \\
4.05\end{array}$ & $\begin{array}{l}1.10 \\
2.25\end{array}$ & $\begin{array}{l}0.03 \\
0.05\end{array}$ & $\begin{array}{l}0.02 \\
0.04\end{array}$ \\
\hline
\end{tabular}


Table.4 Detection of citrus greening disease in three districts of Manipur

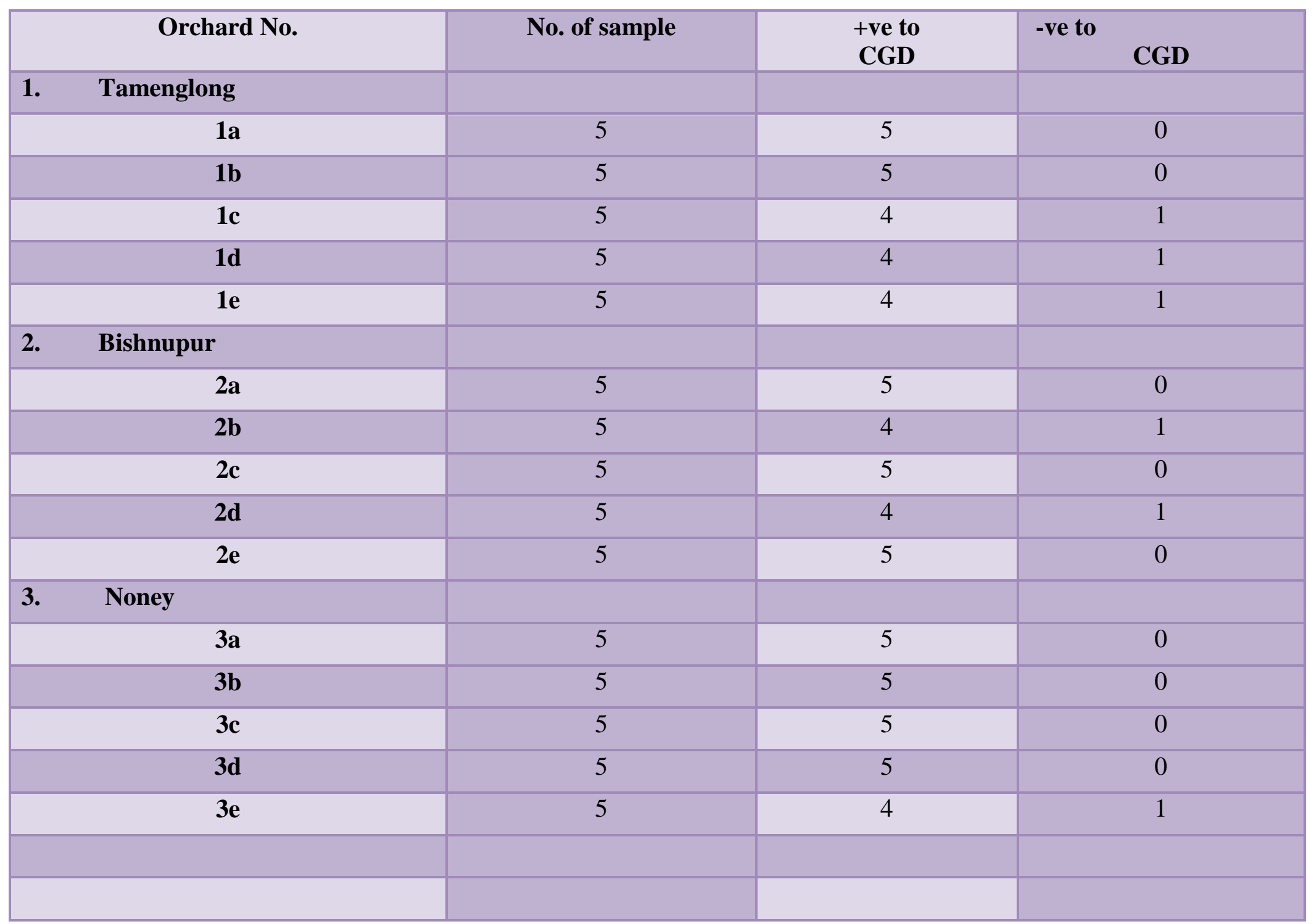




\section{Soil parameters}

The data presented in Table 3 reveals that the soil parameters of Khasi Mandarin showed significant difference among the three districts. Tamenglong district recorded highest 84.88 $\mathrm{mg} / \mathrm{kg} \mathrm{Fe}$ in orchard 1a which was at par with same district of orchards $1 \mathrm{~b}$ and 1c and Noney district of orchard $3 \mathrm{~b}$ and $3 \mathrm{c}$. Bishnupur district recorded lowest Fe content $66.20 \mathrm{mg} / \mathrm{kg}$ in orchard 3e; however, all other orchards from the same district were found low result as compared to Tamenglong and Noney district. On the other hand, $\mathrm{Mn}, \mathrm{Cu}$ and $\mathrm{Zn}$ contents were also found maximum in Tamenglong district $(22.09 \mathrm{mg} / \mathrm{kg}$, $0.87 \mathrm{mg} / \mathrm{kg}$ and $0.75 \mathrm{mg} / \mathrm{kg}$ ) and the lowest was recorded for Bishnupur district $(18.28 \mathrm{mg} / \mathrm{kg}$, $0.57 \mathrm{mg} / \mathrm{kg}$ and $0.47 \mathrm{mg} / \mathrm{kg}$ ). Except Fe content, the distribution of $\mathrm{Mn}, \mathrm{Cu}$ and $\mathrm{Zn}$ content varied from optimum to low to deficient level. In Bishnupur district, $\mathrm{Cu}$ and $\mathrm{Zn}$ content were found to be deficient. From the result, it was observed that growth and yield parameters were found to be the maximum where micro- nutrient contents were also found optimum in the soil.

\section{Detection of citrus greening disease}

The incidence of CGD of 15 orchards were found very high as $88 \%$ in Tamenglong district, $92 \%$ in Bishnupur district and $96 \%$ in Noney district. The detection of CGD was done through iodine based technique and biological indexing (Table 4).

From this investigation, it was concluded that the orchards of three districts belong to Manipur produces mandarin in a limited quantity and production is gradually going to be decline due to heavy infestation of insect, pest and diseases and lower nutrient status of soil. Farmers are also facing a problem on marketing of their produce. Therefore, certain strategy to be followed to increase the yield of mandarin by establishing new orchard with disease free planting material and also proper sanitation and nutrition is required for the maintaining the healthy mandarin crop.

\section{References}

Das, A.K., Sarkar, J., Mondal, B. and Chaudhuri, S. 2004. Variation in plant type and quality characters of Khasi Mandarin (Citrus reticulata Blanco.). The Horticulture Journal. 17(2): 93-100.

Hangsing, H., Mathew, B. and Kalita, D.C. 2016. Performance of Khasi mandarin in Garo Hills of Meghalaya. International Journal of Science Environment and Technology. 5(5): 3213-3223.

Medhi, B.K., Saikia, A.J., Bora, S.C., Hazarika, T.K. and Barbora, A.C. 2007. Integrated use of concentrated organic manures, biofertilizers and inorganic NPK on yield, quality and nutrient content of Khasi Mandarin (Citrus reticulata Blanco.). Indian Journal of Agricultural Research. 41(4): 235-241.

Sarangthem, I.L. and Sharma, D. 2017. Evaluation of nutrient status and development of fertilizer requirements for Khasi mandarin (Citrus reticulata Blanco) grown in Tamenglong district of Manipur. International Journal of Advanced Trends in Engineering, Science and Technology. 2(4): 56-65.

Yadav, D.S., Patel, R.K., Rai, N. and Dubey, A.K. 2003. Physico-chemical status and yield of fruits of declined Khasi Mandarin orchards in Meghalaya. Agriculture Science Digest. 23(1): 71-72.

\section{How to cite this article:}

Kakoti, R.K., Jamini Saikia, Sikha Deka, Arunima Gogoi and Barbora, A.C. 2019. Present Status of Khasi Mandarin in Manipur State of North East India. Int.J.Curr.Microbiol.App.Sci. 8(06): 21572165. doi: https://doi.org/10.20546/ijcmas.2019.806.256 